\title{
THE PROTECTIVE ROLE OF OMEGA-3 AGAINST GENOTOXICITY AND REPRODUCTIVE TOXICITY OF COBALT OXIDE NANOPARTICLES ACUTE TREATMENT IN MALE MICE
}

\author{
NAHED A HUSSIEN*, HANAN R H MOHAMED \\ Department of Zoology, Faculty of Science, Cairo University, Giza 12613, Egypt. Email: nahed199@gmail.com
}

Received: 10 February 2018, Revised and Accepted: 04 April 2018

\begin{abstract}
Objective: Cobalt nanoparticles (NPs), especially cobalt oxide NPs ( $\mathrm{Co}_{3} \mathrm{O}_{4} \mathrm{NPs}$ ) are attracting unique shaped NPs that are used in different biomedical applications and medicine. Different in vitro studies report their toxic and carcinogenic effect but limited in vivo studies were present on its genotoxic potential. The present study was aimed to evaluate the genotoxic potential of $\mathrm{Co}_{3} \mathrm{O}_{4} \mathrm{NPs}$ on bone marrow cells and sperms and the protective role of omega-3 in male albino mice.
\end{abstract}

Methods: Animals were segregated into four groups that were orally treated for 3 consecutive days, Group 1: Negative control; Group 2: Omega-3 (250 mg/kg); Group 3: $\mathrm{Co}_{3} \mathrm{O}_{4} \mathrm{NPs}\left(20 \mathrm{mg} / \mathrm{kg}\right.$ ); and Group 4: Combined group (250 mg/kg Omega-3 and Co $3 \mathrm{O}_{4} \mathrm{NPs} 20 \mathrm{mg} / \mathrm{kg}$ ).

Results: The present results show that $\mathrm{Co}_{3} \mathrm{O}_{4}$ NPs administration significantly increased number of micronucleated polychromatic erythrocytes (PCEs)/1000 PCEs, sperm abnormalities, and DNA damage, significantly decreased sperm motility and concentration in comparison to negative control group. However, Omega-3 administration in the combined group modulates the genotoxic potential of $\mathrm{Co}_{3} \mathrm{O}_{4} \mathrm{NPs}$ in comparison to Co $\mathrm{O}_{4} \mathrm{NPs}$ group.

Conclusion: The present study reports the genotoxic potential of $\mathrm{Co}_{3} \mathrm{O}_{4}$ NPs in vivo and assesses the protective role of 0 mega-3 administration due to its antioxidant effect.

Keywords: $\mathrm{Co}_{3} \mathrm{O}_{4}$ NPs, Omega-3, Micronucleus, Sperm abnormalities, Comet assay.

(c) 2018 The Authors. Published by Innovare Academic Sciences Pvt Ltd. This is an open access article under the CC BY license (http://creativecommons. org/licenses/by/4. 0/) DOI: http://dx.doi.org/10.22159/ajpcr.2018.v11i5.25245

\section{INTRODUCTION}

Cobalt nanoparticles (NPs), especially cobalt oxide NPs $\left(\mathrm{Co}_{3} \mathrm{O}_{4} \mathrm{NPs}\right)$ are attracting enormous interest currently due to their unique shape and size-dependent properties and are used in different biomedical applications and medicine [1,2]. Humans exposed to cobalt NPs from the environment are susceptible to different lung diseases such as fibrosis, interstitial pneumonitis, and asthma [2]. Moreover, IARC [3] evaluated cobalt NPs as a carcinogenic agent.

However, research data on its bioeffects and toxicity are limited. Magaye et al. [2] reported the genotoxic potential of cobalt NPs in vitro. They reported their induction to malignant mesenchymal tumors in rats. In addition, Bucher et al. [4] evaluated carcinogenic potential of cobalt NPs, in which they cause benign lung tumor, bronchioalveolar carcinoma, adenocarcinomas, and bronchioalveolar adenomas in rats that received cobalt NPs for 2 years.

Omega-3 is an essential fatty acid found in large amounts of fish oil. Several researches documented its antioxidant and antiinflammatory potential $[5,6]$. It was reported that Omega-3 fatty acids inhibit proliferation, apoptosis, and promote various cancers differentiation $[7,8]$. Omega-3 fatty acids were found to be hepatic, cardiovascular, and renal protectors; therefore, they have been widely used in clinical perioperative total parenteral nutrition $[9,10]$. In turn, Omega-3 was determined to be a hopeful protector for different tissue cells against various external toxic stimuli.

Mansara et al. [11] reported that Omega-3 supplementation has the ability to significantly $(\mathrm{p}<0.01)$ increase antioxidant enzymes, superoxide dismutases (SOD), glutathione (GSH) reductase and catalase (CAT) enzymes, activity in red blood cells, and the total plasma antioxidant status in breast cancer patients undergoing chemotherapy.
Omega-3 has a protective role against various diseases linked with free radical stress due to its hydroxyl radicals' strong affinity to double bonds that become reduced to single bonds [12].

The present study was aimed to evaluate the genotoxic potential of $\mathrm{Co}_{3} \mathrm{O}_{4}$ NPs on bone marrow cells and sperms of male albino mice. Moreover, we aimed to estimate the protective role of Omega-3 using cytogenetic and molecular evaluations.

\section{METHODS}

\section{Animals}

Twelve mature male Swiss albino mice, weighing about 25-30 g b.w. and aged 10-12 weeks were purchased from National Research Center animal house (Dokki, Giza, Egypt). All experimental procedures and animal maintenance were conducted in accordance with the accepted standards of animal care per cage (Council of Europe, European Convention for the Protection of Vertebrate Animals 2006). We have followed the European Community Directive (86/609/EEC) and National Rules on Animal Care.

\section{Tested drugs}

1. $\mathrm{Co}_{3} \mathrm{O}_{4}$ NPs were purchased from Sigma-Aldrich, USA. The product specification from company conforms its structure through X-ray diffraction. It is a black powder with particle size measurements $\leq 50 \mathrm{~nm}$ using transmission electron microscopy photograph. Trace metal analysis is about $\leq 6000.0 \mathrm{ppm}$, and its purity meets requirements that reach about $99.5 \%$ based on trace metal analysis. They were prepared according to Shaikh and Desai [13], in which $\mathrm{Co}_{3} \mathrm{O}_{4} \mathrm{NPs}$ were suspended directly in $0.9 \% \mathrm{NaCl}$ saline and then sonicated. It is recommended to keep the suspension in a shaker bath at $30^{\circ} \mathrm{C}$ during injection to maintain the suspension.

2. Omega-3 (MONTANA) was purchased from Medizen Pharmaceutical Industries, Egypt (therapeutic dose). 


\section{Treatment schedule}

Mice were segregated into four groups ( 3 mice/each). All mice were orally administrated according to body weight for 3 consecutive days. Group 1: Negative control group and untreated mice; Group 2: Omega-3 group, mice were treated with Omega-3 $(250 \mathrm{mg} / \mathrm{kg})$; Group 3: $\mathrm{Co}_{3} \mathrm{O}_{4}$ NPs, mice were treated with $\mathrm{Co}_{3} \mathrm{O}_{4} \mathrm{NPs}(20 \mathrm{mg} / \mathrm{kg})$; and Group 4: Omega-3 $+\mathrm{Co}_{3} \mathrm{O}_{4}$ NPs group, mice were administrated orally with Omega-3 $(250 \mathrm{mg} / \mathrm{kg})$ simultaneously with $\mathrm{Co}_{3} \mathrm{O}_{4} \mathrm{NPs}(20 \mathrm{mg} / \mathrm{kg})$.

Animals were killed by cervical dislocation, then femoral bones and epididymides were used for further assays.

\section{Cytogenetic evaluations}

\section{Micronucleus (MN) assay}

Bone marrow smears were prepared according to Schmid [14] and then dried smears were fixed in methanol for 5 min and stained with MayGrunwald and Giemsa at pH 6.8.

\section{Semen evaluation of the epididymis}

The cauda epididymides were taken from animals and cut into small pieces in $2 \mathrm{~mL}$ saline. The sperm concentration and motility rate were determined by adding a small amount of sperm suspension in a hemocytometer counting chambers and examined at high magnification light microscope as described by Watanabe and Endo [15]. To determine sperm abnormalities rate, sperm suspension was smeared on a slide, fixed with methanol for $10 \mathrm{~min}$ and stained for 5 mins with $1 \%$ eosin, and then washed with water.

\section{Scoring}

All glass slides were coded before observation and examined under $\times 1000$ magnification using binuclear microscope. For MN assay: 1000 polychromatic erythrocytes (PCEs) per animal were examined for micronucleated PCEs (MnPCEs).

For semen evaluation: Four large counting chambers were counted and substituted in the following equation to estimate sperm concentration and motility. A total of 1000 sperms were counted to determine the percentage of sperm abnormalities.

The sperm concentration $=$ the total sperm number $\div 4 \times 10^{4} \times 2$

The sperm motility rate $=$ the motile sperm number $\div$ the total sperm number $\times 100$.

The sperm abnormality rate=the abnormal sperm number $\div 1000 \times 100$.

\section{Molecular evaluation}

\section{Comet assay}

The alkaline comet assay was performed using bone marrow cells as described in detail by Singh et al. [16]. The slides were stained using $80 \mu \mathrm{L}$ ethidium bromide $(20 \mu \mathrm{g} / \mathrm{mL})$ and then viewed under an epifluorescence microscope (Zeiss epifluoresence) with an attached CCD camera. 50 isolated comets were selected randomly and measured for comet tail length, \% DNA in tail and tail moment using COMETSCORE software based on the definition by Olive and Banath [17].

\section{Statistical analysis}

Data were expressed as the mean \pm standard error $(\mathrm{M} \pm \mathrm{SE})$. Statistical analysis for different assays was performed using student $\mathrm{t}$-test to test the significant difference between groups. All statistics were carried out using statistical analysis systems GraphPad software (GraphPad, 2017) ${ }^{\circledR}$.

\section{RESULTS}

MN assay

Fig. 1a-c shows the induction of Mn in both normochromatic (NCEs) and PCEs erythrocytes due to $\mathrm{Co}_{3} \mathrm{O}_{4} \mathrm{NPs}$ treatment. However, Omega-3 pretreatment in combined group decreases the induction of MnPCEs and MnNCEs as shown in Fig. 1d. The number of MnPCEs/1000 PCEs of mice from $\mathrm{Co}_{3} \mathrm{O}_{4}$ NPs group significantly increased $(\mathrm{p} \leq 0.05)$ in comparison to negative control group. However, Omega-3 of combined group significantly decreased the induction of MnPCEs/1000 PCEs in comparison to mice from $\mathrm{Co}_{3} \mathrm{O}_{4} \mathrm{NPs}$ group still significant in comparison to negative control group (Fig. 2).

\section{Semen evaluation of the epididymis}

Mice treatment with $\mathrm{Co}_{3} \mathrm{O}_{4} \mathrm{NPs}(20 \mathrm{mg} / \mathrm{kg})$ induced different sperm abnormalities as shown in Fig. 3. Sperm abnormalities were amorphous, Hookless, banana-shaped, bent and folded heads, bent and folded tails, and bent and looped midpiece. The percentage of sperm abnormalities is significantly higher in comparison to negative control group.

Omega-3 $(250 \mathrm{mg} / \mathrm{kg})$ treatment for combined group (Omega-3+ $\mathrm{Co}_{3} \mathrm{O}_{4}$ NPs) significantly decreased sperm abnormalities percentage in comparison to $\mathrm{Co}_{3} \mathrm{O}_{4}$ NPs group $(\mathrm{p} \leq 0.05)$ and non-significant to negative control group (Fig. 4).

Moreover, mice from $\mathrm{Co}_{3} \mathrm{O}_{4}$ NPs group significantly decreased sperm concentration in comparison to negative control group. However, Omega-3 treatment for Omega- $3+\mathrm{Co}_{3} \mathrm{O}_{4} \mathrm{NPs}$ group significantly increased sperm concentration in comparison to $\mathrm{Co}_{3} \mathrm{O}_{4}$ NPs group $(p \leq 0.05)$ and non-significant to negative control group as shown in Fig. 4.

In addition, Fig. 5 shows that $\mathrm{Co}_{3} \mathrm{O}_{4} \mathrm{NPs}$ treatment significantly decreased sperm motility in comparison to negative control group. Omega-3 treatment in the combined group significantly increased sperm motility in comparison to $\mathrm{Co}_{3} \mathrm{O}_{4}$ NPs group $(\mathrm{p}<0.05)$ and nonsignificant to negative control group.

\section{Comet assay}

The genotoxic potential of $\mathrm{Co}_{3} \mathrm{O}_{4} \mathrm{NPs}$ was assessed using comet assay, in which Fig. 6a shows typical nuclei of undamaged cells of negative control group; while Fig. 6b represents Omega-3 $(250 \mathrm{mg} / \mathrm{kg})$ treated group that shows normal nuclei of undamaged cells; and Fig. $6 \mathrm{c}$ represents $\mathrm{Co}_{3} \mathrm{O}_{4} \mathrm{NPs}(20 \mathrm{mg} / \mathrm{kg})$ treated group that shows severe DNA damage observed as comets and Fig. 6d shows normal nuclei of undamaged cells of combined (Omega-3+ $\mathrm{Co}_{3} \mathrm{O}_{4} \mathrm{NPs}$ ) group. Fifty isolated comets were randomly selected for all groups and measured for comet tail length, \% DNA in tail and tail moment using COMETSCORE software. The results show a significant increase in tail length and tail moment

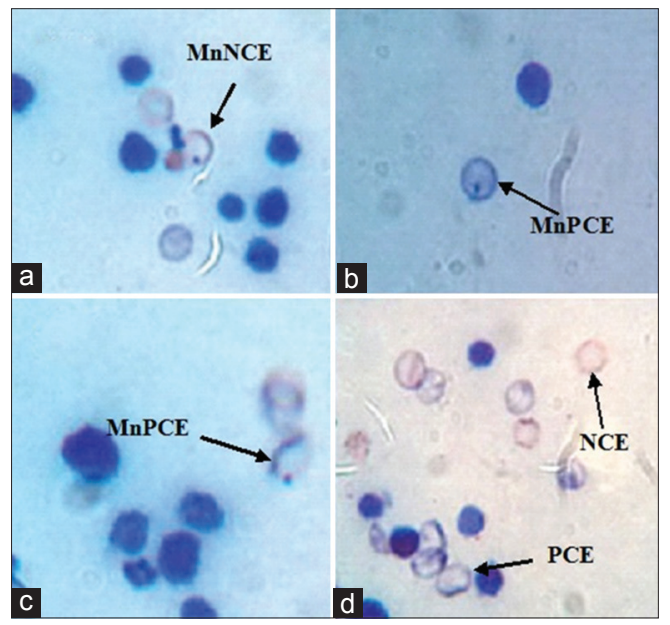

Fig. 1: Representative photomicrographs showing the genotoxic effect of cobalt oxide nanoparticles $(20 \mathrm{mg} / \mathrm{kg} / \mathrm{day})$ treatment in mice bone marrow cells (a-c) and the protective role of Omega-3 $(250 \mathrm{mg} / \mathrm{kg})$ (d). In which, A shows micronucleated normochromatic erythrocytes (MnNCEs), while b-d show MnPCEs with only one micronucleus per cell. PCE represents PCEs and NCE represents normochromatic erythrocytes 


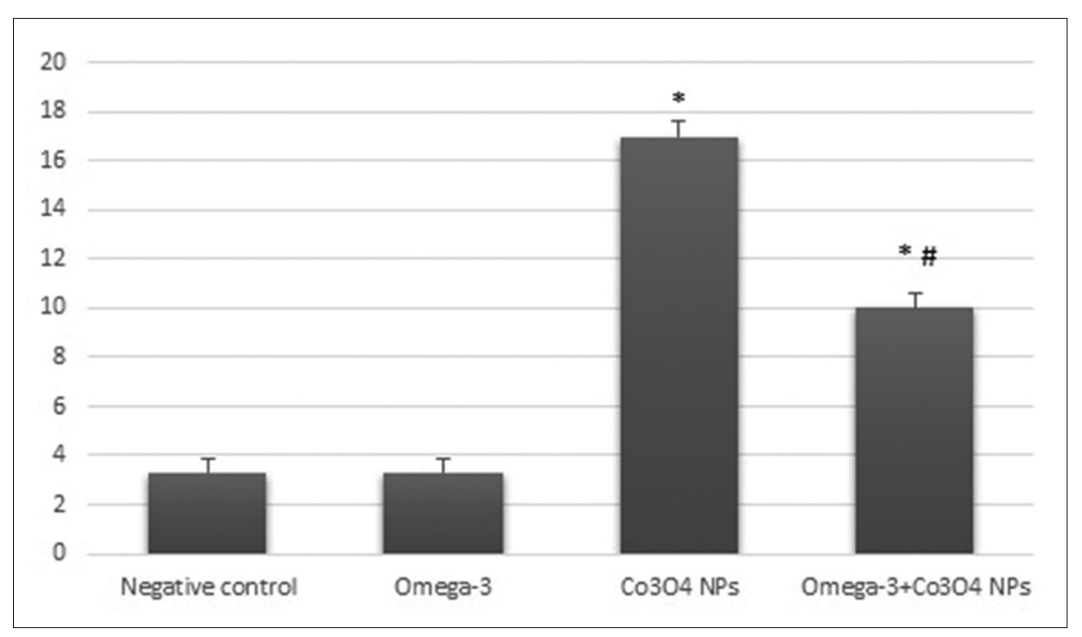

Fig. 2: Effect of cobalt oxide nanoparticles $(20 \mathrm{mg} / \mathrm{kg} / \mathrm{day})$ treatment and the mitigating role of Omega-3 $(250 \mathrm{mg} / \mathrm{kg}) \mathrm{on} \mathrm{the} \mathrm{number} \mathrm{of}$ micronucleated polychromatic erythrocytes induction in bone marrow cells of mice. Significant difference $(p<0.05)$ between compared groups using student t-test. *Statistically compared with negative control group. \#Statistically compared with Co304 NP group

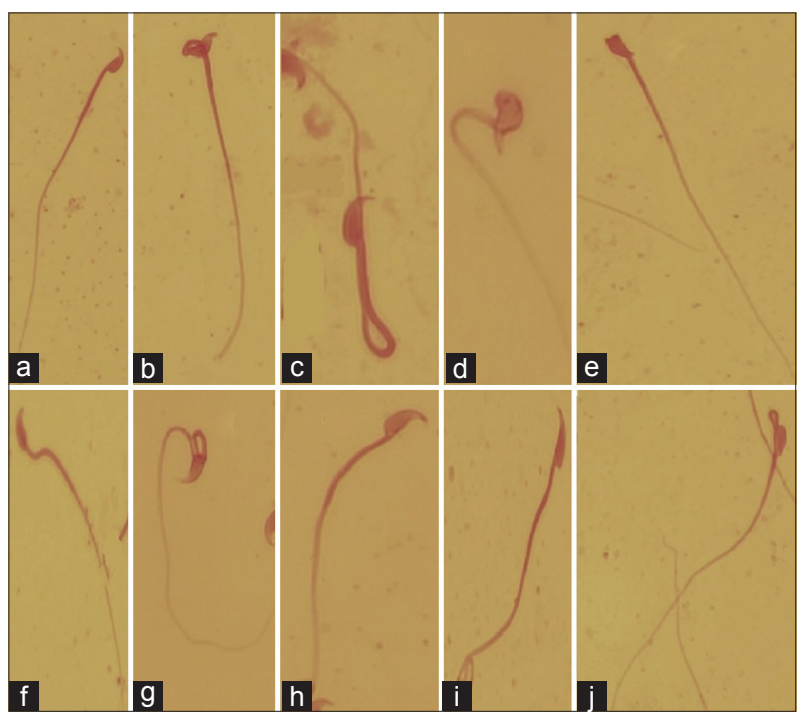

Fig. 3: Representative photomicrograph for the observed normal and abnormal sperms for different untreated and treated mice. In which, (a) represents normal hooked sperm; (b) represents bent and hookless head; (c) represents bent tail; (d) shows amorphous head with a bent midpiece; (e) shows bent head; (f) shows hookless head with a bent midpiece; (g) represents looped midpiece; (h) represents folded tail; (i) shows banana head sperm with a folded tail; and (j) shows sperm with a looped midpiece and hookless head

$(\mathrm{p}<0.05)$ for both Omega-3 and $\mathrm{Co}_{3} \mathrm{O}_{4}$ NPs groups and \% DNA in tail for $\mathrm{Co}_{3} \mathrm{O}_{4} \mathrm{NPs}$ group in comparison with the negative control group (Fig. 7).

Omega-3 treatment of combined group shows a significant decrease $(p<0.05)$ of \% DNA in tail and tail moment and remarkable decrease of tail length in comparison with $\mathrm{Co}_{3} \mathrm{O}_{4} \mathrm{NPs}$ group. This decrease is nonsignificant to negative control group except for \% DNA in tail.

\section{DISCUSSION}

The present study reports the genotoxic potential of $\mathrm{Co}_{3} \mathrm{O}_{4}$ NPs $(20 \mathrm{mg} / \mathrm{kg})$ in bone marrow cells and sperms in male albino mice. Our results were in agreement with several different in vitro and few in vivo results that estimated the genotoxic effect of cobalt NPs. In which, Ponti et al. [18] observed that cobalt NPs $(>1 \mu \mathrm{M})$ induced an increased production of single- and double-strand DNA breaks as well as chromosomal aberrations in the form of micronucleate binucleate cells in BALB/3T3 mouse fibroblast cells. It was reported that cobalt NPs increased DNA damage by the comet assay and positive results in MN assay in human peripheral leukocytes [19].

However, very few in vivo studies were done on cobalt NPs genotoxicity. Klien and Godnić-Cvar [20] believed that the Co NPs have rarely been considered to induce DNA damage in vivo. Hereby, we have recorded a significant induction of MN in MnPCEs/1000 PCEs that might be due to chromosomal break/damage leaving a part of chromosome or the whole chromosome in the mature cell [21], reproductive toxicity appeared in the form of decrease in sperm motility, concentration, and increased sperms abnormalities and DNA damage in comet assay in comparison to negative control group. Recently, Hwang et al. [22] investigated genotoxicity of Co NPs dependent on surface coating. They reported that silica-coated and uncoated cobalt ferrite accumulated in liver tissue, while only uncoated $\mathrm{CoFe}_{2} \mathrm{O}_{4} \mathrm{NPs}$ resulted in enhanced expression of genes related to DNA damage and repair, carcinogenesis, cell death, growth arrest, oxidative stress, and inflammation in mice.

Wise et al. [23] suggested that oxidative stress has a playing important role in the toxicity mechanism of different NPs through either the excessive induction of reactive oxygen species (ROS) or depletion of cellular antioxidant capacity, in which induction of free radicals as the superoxide radical $\left(\mathrm{O}_{2}-\right), \mathrm{H}_{2} \mathrm{O}_{2}$, and the hydroxyl radical $(\cdot \mathrm{OH})$ represent the main cause of DNA damage and can leads to cell apoptosis and death [24]. Therefore, ROS induction might be the main reason for $\mathrm{Co}_{3} \mathrm{O}_{4} \mathrm{NPs}$ DNA damage that leads to genotoxicity and reproductive toxicity that was explained before by Alarifi et al. [25].

Alarifi et al. [25] reported that $\mathrm{Co}_{3} \mathrm{O}_{4} \mathrm{NPs}$ significantly altered oxidant/ antioxidant levels in HepG2 cells due to ROS, lipid peroxidation endpoint product (malondialdehyde, [MDA]), SOD, and CAT activities increased induction, while significantly decreased GSH antioxidant product. They believed that the disturbance of oxidant/antioxidant balance leads to induction of different free radicals $\mathrm{O}^{2-}, \mathrm{OH}^{*}$, and $\mathrm{H}_{2} \mathrm{O}_{2}$ that elicit a variety of physiological and cellular events, including inflammation, DNA damage, and apoptosis [26].

Treatment of HepG2 cells with cobalt NPs exposure leads to increase in caspase-3 levels [25] that are essential for cellular DNA damage and apoptosis [27].

Therefore, the main genotoxic target of cobalt NPs could be considered due to oxidative stress that leads to DNA damage and cell apoptosis. 


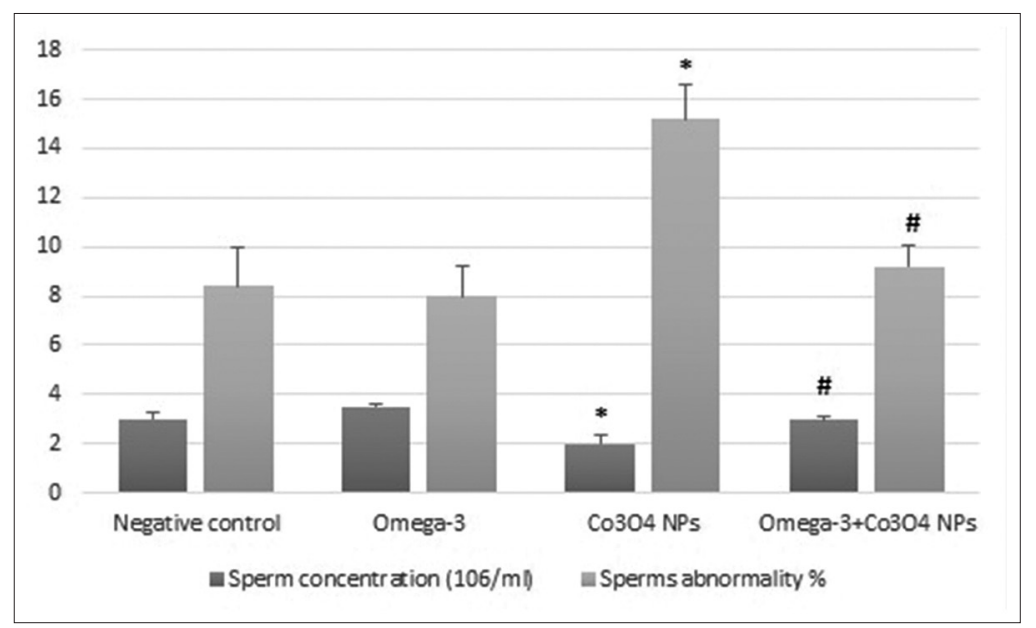

Fig. 4: The genotoxic effect of cobalt oxide nanoparticles $\left(\mathrm{Co}_{3} \mathrm{O}_{4} \mathrm{NPs}\right)(20 \mathrm{mg} / \mathrm{kg})$ treatment on sperm concentration and the percentage of sperm abnormalities in cauda epididymides of mice. Significant difference ( $p \leq 0.05)$ using student's $t$-test, in which: *Statistically compared with negative control group; \#Statistically compared Omega-3+ $\mathrm{Co}_{3} \mathrm{O}_{4} \mathrm{NPs}$ group with $\mathrm{Co}_{3} \mathrm{O}_{4} \mathrm{NPs}$ group

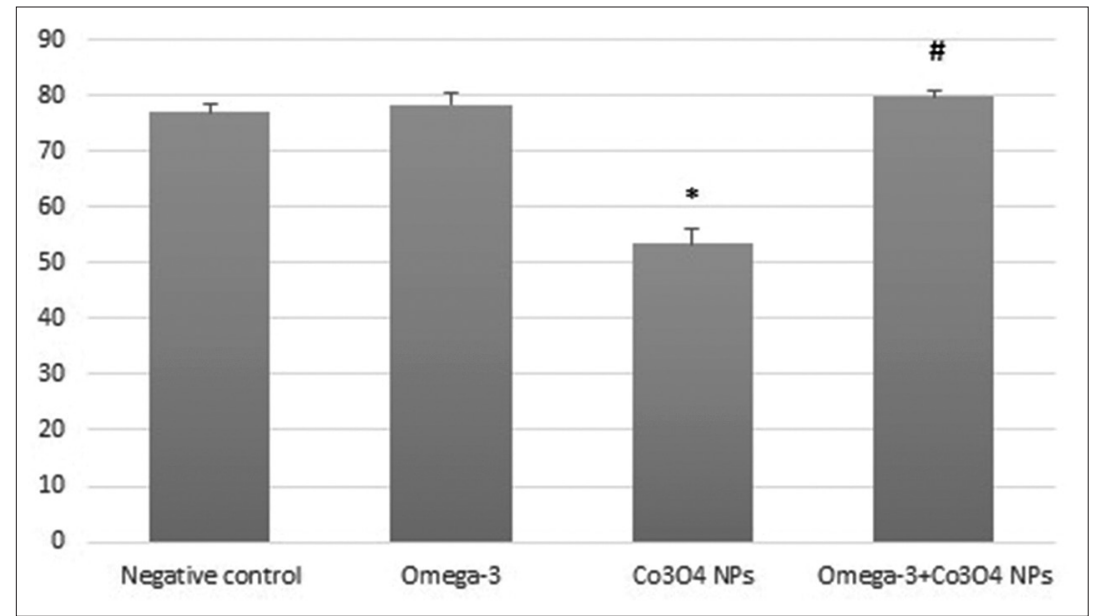

Fig. 5: The effect of cobalt oxide nanoparticles (Co304 NPs) $(20 \mathrm{mg} / \mathrm{kg})$ treatment on the percentage of sperm motility in cauda epididymides of mice. Significant difference $(p \leq 0.05)$ using student's t-test, in which: *Statistically compared with negative control group; \#Statistically compared Omega-3+ Co304 NPs group with Co304 NPs group

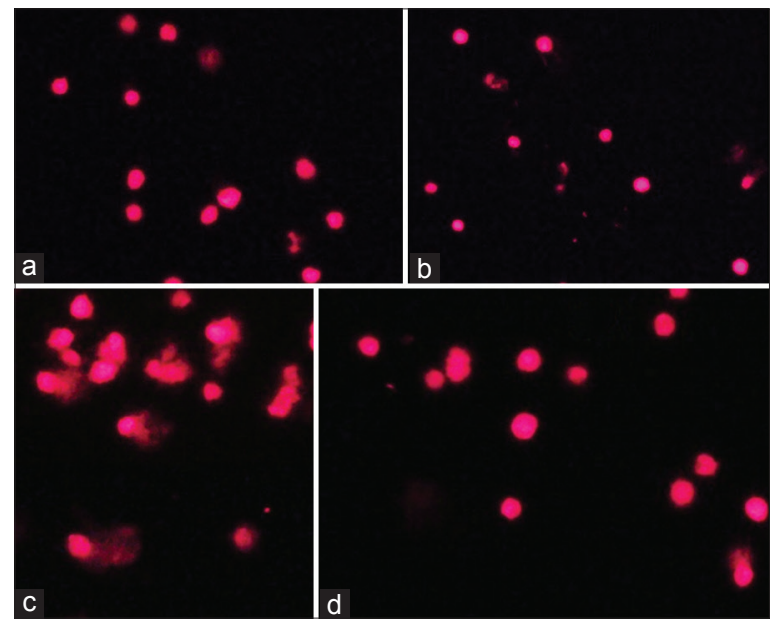

Fig. 6: Representative photomicrograph showing (a) typical nuclei of undamaged cells of negative control group; (b) Omega-3 group; (c) DNA damage observed as comets that were seen in cobalt oxide nanoparticles $\left(\mathrm{Co}_{3} \mathrm{O}_{4} \mathrm{NPs}\right)$ group; and (d) combined Omega- $3+\mathrm{Co}_{3} \mathrm{O}_{4} \mathrm{NPs}$ group
The use of helpful antioxidant could be a good idea to overcome the NP toxicity by its scavenger properties.

The present study reports the protective effect of Omega- $3(250 \mathrm{mg} / \mathrm{kg})$ by modulating the genotoxic potential of $\mathrm{Co}_{3} \mathrm{O}_{4} \mathrm{NPs}$ in the combined group. In which, it significantly decreases the induction of MnPCEs/1000, sperm abnormalities and DNA damage and increases sperm motility and concentration in comparison to $\mathrm{Co}_{3} \mathrm{O}_{4} \mathrm{NPs}$ group. Elelaimy et al. [28] elicited the antigenotoxic potential of oral administration of Omega-3 either before or after treatment of the anticancer drug (azathioprine) in male albino mice. In which, they estimated that Omega- 3 was effective to reduce the frequencies of MnPCEs, quantitatively decreased the DNA fragmentation as a marker of apoptosis, total sperm different abnormalities and significantly increased sperm number, percentage of PCEs, and enhanced the ratio of PCEs to NCEs (as a marker to cytotoxicity). Moreover, they record the antigenotoxic effect of Omega-3 using polymorphism of DNA (RAPD) assay, that showed distinct differences in animal groups intoxicated with Azathioprine before and after Omega-3 treatment, which reflected DNA protective effect of Omega-3.

These results were in agreement with previous studies, in which Abdou and Hassan [29] reported the protective role of Omega-3 fatty acids 


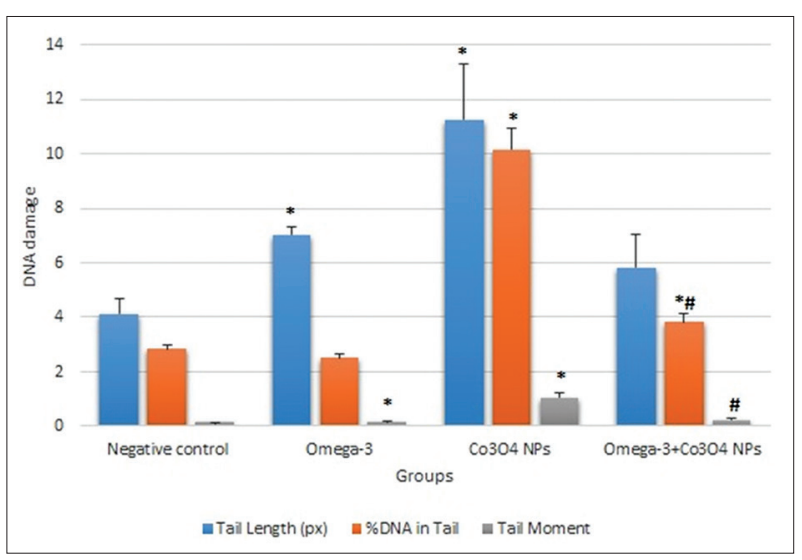

Fig. 7: Effect of Omega-3 $(250 \mathrm{mg} / \mathrm{kg})$ on the DNA damage as a result of cobalt oxide nanoparticles $\left(\mathrm{Co}_{3} \mathrm{O}_{4} \mathrm{NPs}\right)(20 \mathrm{mg} / \mathrm{kg})$ treatment in mice bone marrow cells (represented by comet assay). Significant difference $(\mathrm{p}<0.05)$ using student's t-test, in which: *Statistically compared with negative control group; \#Statistically compared Omega-3+ $\mathrm{Co}_{3} \mathrm{O}_{4} \mathrm{NPs}$ group with $\mathrm{Co}_{3} \mathrm{O}_{4}$ NPs group

( 125 and $260 \mathrm{mg} / \mathrm{kg}$ body weight) in female rats exposed to lead acetate (25 mg/kg body weight). In which, Omega-3 in combined groups with lead acetate normalized the lipid profiles in the serum, hematological parameters, WBCs count and improved the kidney histology to reach the negative control values and architectures.

Recent research evaluated the protective role of fish Omega-3 fatty acids $(400 \mathrm{mg} / \mathrm{kg}$, for 30 days by intragastric gavage) on doxorubicin (30 $\mathrm{mg} / \mathrm{kg}$, single intraperitoneal injection)-induced testicular apoptosis and oxidative damage in male rats [30]. In addition, Mansara et al. [11] estimated in a case report on five Indian women with breast cancer that supplementation of fish oil significantly $(\mathrm{p}<0.01)$ increased SOD, GSH reductase, and CAT activity in red blood cells and the total plasma antioxidant status in the patients. They concluded that Omega-3 fatty acids might be an alternative adjuvant treatment for breast cancer instead of chemotherapy due to its antioxidant potential.

Abdou and Hassan [29] indicated that Omega-3 treatment decreased the level of MDA in lead-acetate genotoxic induced groups due to its antioxidant properties to inhibit lipid peroxidation [31] that, in turn, helps to stabilize the reactive radicals and protect cell from damage. Moreover, it was reported that Omega-3 treatment prevented GSH level reduction through protecting the $\mathrm{SH}$ group from the reactive free radicals. In addition, it was found that Omega- 3 could maintain normal levels of SOD and CAT activities [32]. Therefore, Omega-3, the naturally occurring antioxidant has the ability to scavenge free radical elicited due to $\mathrm{Co}_{3} \mathrm{O}_{4}$ NPs treatment and, in turn, reduce DNA damage in Comet assay, chromosomal damage in MN assay and reproductive toxicity in sperms.

\section{CONCLUSION}

The present study reports the genotoxic potential of $\mathrm{Co}_{3} \mathrm{O}_{4} \mathrm{NPs}\left(\mathrm{Co}_{3} \mathrm{O}_{4}\right.$ NPs, $20 \mathrm{mg} / \mathrm{kg}$ ) in bone marrow cells and reproductive toxicity of sperms in male albino mice. The antioxidant potential of Omega- 3 could be the main target to modulate the genotoxic effect induced by $\mathrm{Co}_{3} \mathrm{O}_{4}$ NPs treatment to maintain the oxidant/antioxidant balance. However, more in vivo studies are needed to fully understand the mechanism of cobalt NPs genotoxicity and the antigenotoxic effect of Omega-3.

\section{AUTHORS CONTRIBUTIONS}

Nahed A. Hussien contributed in methodology, results interpretation and statistical analysis and wrote the manuscript. Hanan R. H. Mohamed suggested the aim of work, contributed in methodology and revised the final version of manuscript.

\section{CONFLICT OF INTEREST}

The authors have declared no conflict of interest.

\section{REFERENCES}

1. Rebello V, Shaikh S, Desai PV. 'Toxicity of Cobalt Oxide Nanoparticles" Environmental Engineering and Applications (ICEEA). In: International Conference on 10-12 Sept; 2010. p. 195-9.

2. Magaye R, Zhao J, Bowman L, Ding M. Genotoxicity and carcinogenicity of cobalt-,nickel- and copper-based nanoparticles. Exp Ther Med 2012;4:551-61.

3. International Agency for Research on Cancer (IARC). IARC Graphs on the Evaluation of Carcinogenic Risks to humans. In: Chlorinated Drinking Water, Chlorinated by-products, Some Other Halogenated Compounds, Cobalt and Cobalt Compounds, 52. Lyon, France: IARC; 1991. p. 1-554.

4. Bucher JR, Hailey JR, Roycroft JR, Haseman JR, Sills RC, Grumbein SL, et al. Inhalation toxicity and carcinogenicity studies of cobalt sulfate. Toxicol Sci 1999;49:56-67.

5. Zararsiz I, Sonmez MF, Yilmaz HR, Tas U, Kus I, Kavakli A, et al. Effects of omega-3 essential fatty acids against formaldehyde-induced nephropathy in rats. Toxicol Ind Health 2006;22:223-9.

6. Ozen OA, Cosar M, Sahin O, Fidan H, Eser O, Mollaoglu H, et al. The protective effect of fish n-3 fatty acids on cerebral ischemia in rat prefrontal cortex. Neurol Sci 2008;29:147-52.

7. Edwards IJ, O'Flaherty JT. Omega-3 fatty acids and PPAR - in cancer. PPAR Res 2008;8:358052.

8. Sun WH, Chen GS, Ou XL, Yang Y, Luo C, Zhang Y, et al. Inhibition of COX-2 and activation of peroxisome proliferator-activated receptor - synergistically inhibits proliferation and induces apoptosis of human pancreatic carcinoma cells. Cancer Lett 2009;275:247-55.

9. Fassett RG, Gobe GC, Peake JM, Coombes JS. Omega-3 polyunsaturated fatty acids in the treatment of kidney disease. Am J Kidney Dis 2010;56:728-42.

10. Koletzko B, Goulet O. Fish oil containing intravenous lipid emulsions in parenteral nutrition-associated cholestatic liver disease. Curr Opin Clin Nutr Metab Care 2010;13:321-6.

11. Mansara P, Ketkar M, Deshpande R, Chaudhary A, Shinde K, KaulGhanekar R. Improved antioxidant status by omega-3 fatty acid supplementation in breast cancer patients undergoing chemotherapy: A case series. J Med Case Rep 2015;9:148.

12. Czapski G. Reactions of $\mathrm{OH}$ radical. Methods Enzymol 1984;105:209-15.

13. Shaikh SM, Desai PV. Effect of $\mathrm{CoO}$ nanoparticles on the carbohydrate metabolism of the brain of mice "Mus musculus". J Basic Appl Zool 2016;77:1-7.

14. Schmid W. The micronucleus test. Mutat Res 1975;31:9-15.

15. Watanabe T, Endo A. Effects of selenium deficiency on sperm morphology and spermatocyte chromosomes in mice. Mutat Res 1991;262:93-9.

16. Singh NP, McCoy MT, Tice RR, Schneider EL. A simple technique for quantitation of low levels of DNA damage in individual cells. Exp Cell Res 1988;175:184-91.

17. Olive PL, Banath JP. Induction and rejoining of radiation-induced DNA single-strand breaks: "Tail moment" as a function of position in the cell cycle. Mutat Res 1993;294:275-83.

18. Ponti J, Sabbioni E, Munaro B, Broggi F, Marmorato P, Franchini F, et al. Genotoxicity and morphological transformation induced by cobalt nanoparticles and cobalt chloride: An in vitro study in Balb/3T3 mouse fibroblasts. Mutagenesis 2009;24:439-45.

19. Colognato R, Bonelli A, Ponti J, Farina M, Bergamaschi E, Sabbioni E, et al. Comparative genotoxicity of cobalt nanoparticles and ions in human peripheral leukocytes in vitro. Mutagenesis 2008;23:377-82.

20. Klien K, Godnić-Cvar J. Genotoxicity of metal nanoparticles: Focus on in vivo studies. Arh Hig Rada Toksikol 2012;63:133-45.

21. Fenech M, Kirsch-Volders M, Natarajan AT, Surralles J, Crott JW, Parry J, et al. Molecular mechanisms of micronucleus, nucleoplasmic bridge and nuclear bud formation in mammalian and human cells. Mutagenesis 2011;26:125-32.

22. Hwang DW, Lee DS, Kim S. Gene expression profiles for genotoxic effects of silica-free and silica-coated cobalt ferrite nanoparticles. J Nucl Med 2012;53:106-12.

23. Wise JP, Goodale BC, Wise SS. Silver nanospheres are cytotoxic and genotoxic to fish cells. Aquat Toxicol 2010;97:34-41.

24. Ott M, Gogvadze V, Orrenius S, Zhivotovsky B. Mitochondria, oxidative stress and cell death. Apoptosis 2007;12:913-22. 
25. Alarifi S, Ali D, Y AO, Ahamed M, Siddiqui MA, Al-Khedhairy AA. Oxidative stress contributes to cobalt oxide nanoparticles-induced cytotoxicity and DNA damage in human hepatocarcinoma cells. Int J Nanomed 2013;8:189-99.

26. Asharani PV, Mun GK, Hande MP, Valiyaveettil S. Cytotoxicity and genotoxicity of silver nanoparticles in human cells. ACS Nano 2009;3:279-90.

27. Janicke RU, Sprengart ML, Wati MR, Porter AG. Caspase- 3 is required for DNA fragmentation and morphological changes associated with apoptosis. J Biol Chem 1998;273:9357-60.

28. Elelaimy IA, Elfiky SA, Hassan AM, Ibrahim HM, Elsayad RI. Genotoxicity of anticancer drug Azathioprine (Imuran): Role of omega-3 ( $\omega$-3) oil as protective agent. J Appl Pharm Sci 2012;2:14-23.
29. Abdou HM, Hassan MA. Protective role of omega-3 polyunsaturated fatty acid against lead acetate-induced toxicity in liver and kidney of female rats. BioMed Res Int 2014;2014:1-11.

30. Uygur R, Aktas C, Tulubas F, Uygur E, Kanter M, Erboga M, et al. Protective effects of fish omega-3 fatty acids on doxorubicin-induced testicular apoptosis and oxidative damage in rats. Andrologia 2014;46:917-26.

31. Pauwelsand EK, Kostkiewicz M. Fatty acid facts, part III: Cardiovascular disease, or, a fish diet is not fishy. Drug News Perspect 2008;21:552-61.

32. Attia AM, Nasr HM. Dimethoate-induced changes in biochemical parameters of experimental rat serum and its neutralization by black seed (Nigella sativa L.) oil. Slovak J Anim Sci 2009;42:87-94. 